\title{
Human Capital Accountability and Construct: Evidence from Islamic Microfinance Institutions in Malaysia
}

\author{
Amrizah Kamaluddin \\ Accounting Research Institute \& Faculty of Accountancy, Universiti Teknologi MARA \\ 43000 Selangor, Malaysia \\ Tel: +60332587401 Email: amrizah@salam.uitm.edu.my \\ (corresponding author)
}

\section{Nawal Kassim}

Accounting Research Institute \& Faculty of Accountancy, Universiti Teknologi MARA 43000 Selangor, Malaysia

Tel: +60355444952 Email: nawal120@salam.uitm.edu.my,

Md. Mahmudul Alam

School of Economics, Finance \& Banking, College of Business, Universiti Utara

Malaysia, Kedah, Malaysia

Tel: +6018-246 7050 Email: $\underline{\text { rony000@gmail.com }}$

\section{Siti Akmar Abu Samah}

Akademi Pengajian Bahasa,Universiti Teknologi MARA 43000 Selangor, Malaysia

Tel: +603-5544 2400 Email: sitiakma@ salam.uitm.edu.my

\section{Citation Reference:}

Kamaluddin, A., Kassim, N., Alam, M.M., \& Samah, A.A. (2018). Human Capital Accountability and Construct: Evidence from Islamic Microfinance Institutions in Malaysia. Global Journal Al-Thaqafah, Special Issue, 117-129. (online) http://www.gjat.my/gjat2018si/SI2018-08.pdf

This is a pre-publication copy.

The published article is copyrighted by the publisher of the journal. 


\title{
Human Capital Accountability and Construct: Evidence from Islamic Microfinance Institutions in Malaysia
}

\begin{abstract}
To identify the human capital construct that significantly relates to the performance of Islamic organizations, this study obtained data from Islamic microfinance organizations in Malaysia using the survey questionnaire method. In addition, we interviewed renowned scholars in the fields of Islamic accounting and Shariah law. Consequently, this study proposes an extended model of human capital that is applicable to Islamic organizations. Apart from knowledge and competency, this study includes spiritual value as another construct of human capital in Islamic organizations. Knowledge includes ideas that are relevant to the accounting and auditing spectra, as well as Shariah principles and jurisprudence. By contrast, competency refers to the ability to innovate unique Shariah-compliant products that are rare and difficult to imitate. Meanwhile, spiritual values embrace the elements of "Siddiq," "Amanah," "Fathonah," and "Tabligh." This study affirms that knowledge, competency, and satisfaction are the most significant constructs of human capital that explain performance. Factor analysis indicates that spiritual value is embedded in and forms part of the human capital construct. Hence, spiritual value is a key element in company culture and contributes significantly to organizational success. This model can be a platform for human capital reporting in the relevant Islamic and conventional organizations.
\end{abstract}

Keywords: Intellectual capital, Human capital; Islamic Organization; Microfinance Organization; Human spirit.

\section{Introduction}

Human capital is vital to organizational success, and is defined as the stock of competency, knowledge, and personality attributes that is utilized to produce economic value and enhance firm performance. Human capital is also related to the employee- and firm-based skill and knowledge components of intellectual capital(Uliana, Macey, \& Grant, 2005). The individual capabilities, knowledge, skills, and experiences of a company's employees and managers are crucial to the firm because these factors contribute to its competitive advantage and facilitate the maximization of profits (Aradhana \& Anuradha, 2005; Kazemian, Abdul Rahman, Mohd Sanusi, \& Adeyemi, 2016; Wright, McMahan, \& McWilliams, 1994). This idea is consistent with Amrizah Kamaluddin and Rahman (2013) who concluded that employees' sustainability and satisfaction are components of human capital attributes.

Further, Baron (2011)asserted that human capital is generally an element of intellectual capital. The former could be integrated with social and organizational capital. Social capital comprises the relationships and networks that permit the creation and transfer of knowledge, whereas organizational capital includes a firm's policies, procedures, 
patents, and other forms of knowledge owned by an organization. The value of human capital depends on its potential to contribute toward a firm's competitive advantage or core competency. The development of human capabilities and skills significantly contributes towards economic development (Abdullah, 2012). Human capital can be developed by improving the skills and competencies of people through education and effective human resource management. The value of human capital in organizations can be increased by attracting skilled individuals from the external labor market or by internally developing the skills of current employees through training and development, among others (Darus, Mad, \& Yusoff, 2014; Kazemian, Abdul Rahman, \& Ibrahim, 2014; Paula \& Michela, 2010).

Baron (2011) affirmed that a high value of human capital does not consistently translate to high organizational value. All forms of capital must be evaluated and analyzed in the context of understanding how people drive business performance. The value creation of a company, which comprises talented human capital, is not guaranteed if production or marketing processes (i.e., structural capital) are not well-organized or customers (i.e., relational capital) are not reached(Hermans \& Kauranen, 2005). Consequently, human and relational capital requires strong organizational procedures, databases, and processes (i.e., structural capital) to translate to good firm performance. Human and relational capital assist in strengthening structural capital, which is proprietary and not self-renewing (Roos, Roos, Dragonetti, \& Edvinsson, 1997).

In the Islamic context, human capital is the ability and experience of a human being to fulfill one's objective and responsibility in this world as a trustee of Allah (SWT), as well as be accountable for all his actions in the Hereafter (Abdullah, 2012; Mohamed et al., 2013). From the Islamic perspective, a comprehensive model of human capital development includes moral, ethical, intellectual, and physical development without neglecting the development of skills and expertise. In addition, the aim of the human capital development in Islam is for an individual to achieve quality and competency to the best of his ability to fulfill his responsibilities and duties as a human being. Islam requires human capital development to realize competency, which can be achieved by acquiring a variety of knowledge and skills. Consequently, the acquired skills and knowledge of an employee will further contribute to the core competency and competitive advantage of his organization, as well as to the development of society. However, the parties involved in any form of transactions should have unity of mind and sincerity in their actions. That is, utmost good faith should be observed in all spheres of dealings because no room or excuse is provided for those who act with a malicious intent to deceive(Mohd Ma'sum Billah, 2003). The justification of this principle in the Qur'an (61:2-3) is translated as follows:

"O you who believe: Why say you that which you do not? Grievously adious is it in the Sight of Allah (SWT) that you say that which you do not."

This code is also mentioned in another section in the Qur'an (16:90), which is translated as follows:

"Verily Allah (SWT) commands justice and the doing of good." 
Hence,

capital is

when

is

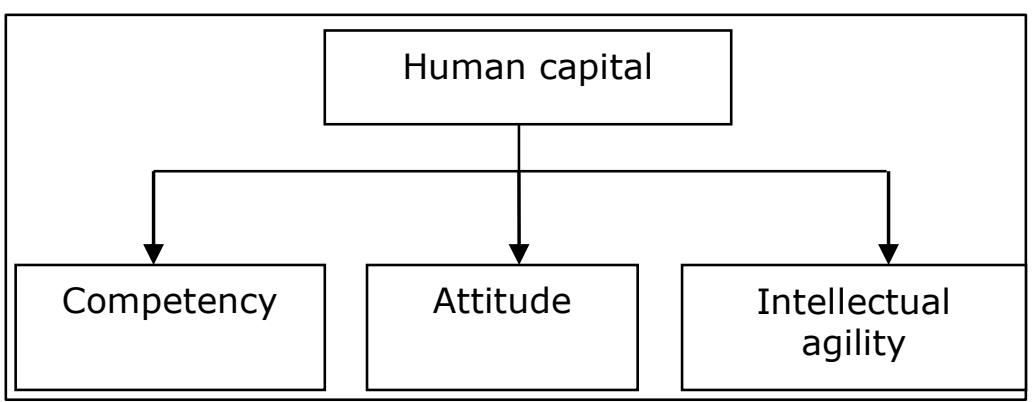

human

different

from the

viewed

Islamic and

conventional perspectives. In Islam, human capital covers all aspects of life. By contrast, the conventional perspective only focuses on human capital as a tool for maximizing organizational profit and achieving organizational goals. In addition, the foundation of Islamic human capital development is based on the Qur'an and Sunnah, whereas conventional human capital development only refers to ethics based on manmade laws.

Tan Sri Dr. Zeti Akhtar Aziz, the governor of the Central Bank of Malaysia (The Global Islamic Financial Services Industry, 2007), regards the importance of human intellectual capital from the perspective of Islamic finance as follows:

"...an important factor in sustaining the performance and competitiveness of the Islamic financial industry. Indeed, the fast pace of innovation in global financial services in general and in the Islamic financial service sector in particular, demands new expertise and skills." (p. 2)

Conventional human capital theory mainly focuses on the development of institutional education, skills, and expertise. Therefore, this study aims to demonstrate how the measurement of human capital has facilitated the development of Islamic organizations and to identify the human capital construct that significantly relates to performance. For the purpose of this research, Islamic microfinance institutions are taken as the sample.

\section{Literature Review}

\section{Human Capital Model}

The current model of human capital includes intangible elements, such as competency, attitude, and intellectual agility, as components of human capital (see Figure 1)(Roos et al., 1997). 
The main components of competency are knowledge and skills. Knowledge refers to technical or academic knowledge, which is acquired from schools, universities, and organization field training, as well as the educational level of employees. Knowledge also covers the theoretical aspect of an employee and is complemented with skills. Skill is the ability to handle a practical application of knowledge, such as the use of a computer, which can be accomplished by using information technology literacy (Roos et al., 1997; Shuhidan, Said, Mokri, \& Kazemian, 2016).

Firms require employees with strong character and are able and willing to apply their knowledge and skills to achieve organizational goals. These factors are influenced by the attitude of employees. Attitude is affected by motivation, behavior, and conduct(Roos et al., 1997). Davenport (1999)described human capital as comprising ability, behavior, effort, and time, all of which are owned and controlled by workers.

To adapt to the -rapidly changing economic environment, firms should have employees with intellectual agility. Intellectual agility is the ability to transfer knowledge from one context to another (e.g., the ability to innovate and transform ideas to products and services, as well as improve knowledge and the company, thereby possibly leading to successful diversification)(Roos et al., 1997).

The aforementioned definition of human capital is confirmed by intellectual capital scholars, who claim that human capital is sourced from the talents of employees(Stewart, 2002) which include skills, brainpower, and tacit knowledge(AlAli, 2003) Thus, human capital is a source of innovation and strategic renewal(Brinker, 2005; Nick, 1998; Seetharaman, Kevin Lock Teng, \& Saravanan, 2004). Human capital is "the collective capability of the firm to extract the optimum solutions from employee knowledge and is a direct consequence of the sum of workforce expertise, knowledge, and attitude(Tseng \& James Goo, 2005, p. 194).” Hubert (1996)defined human capital as the capabilities of individuals that are required to provide solutions to or serve clients.

From the perspective of Islamic finance institutions, the board of directors and Shariah supervisory board are two independent bodies that play a major role in the intellectual capital model (see Figure 2). This intellectual capital model, which was proposed by Nicholson and Kiel (2004), divides intellectual capital into the human, social, and structural capital components. In this regard, human capital comprises the individual skills and knowledge that constitute the experiences of the members of the board of directors and the Shariah supervisory board, as well as assist in their decisionmaking(Nick, 1999). These components are the primary constituents of intellectual capital, which forms the basis of a board's functionality(Bassi \& Buren, 1999)and influences the effectiveness of the board members(Castanias \& Helfat, 2001). 


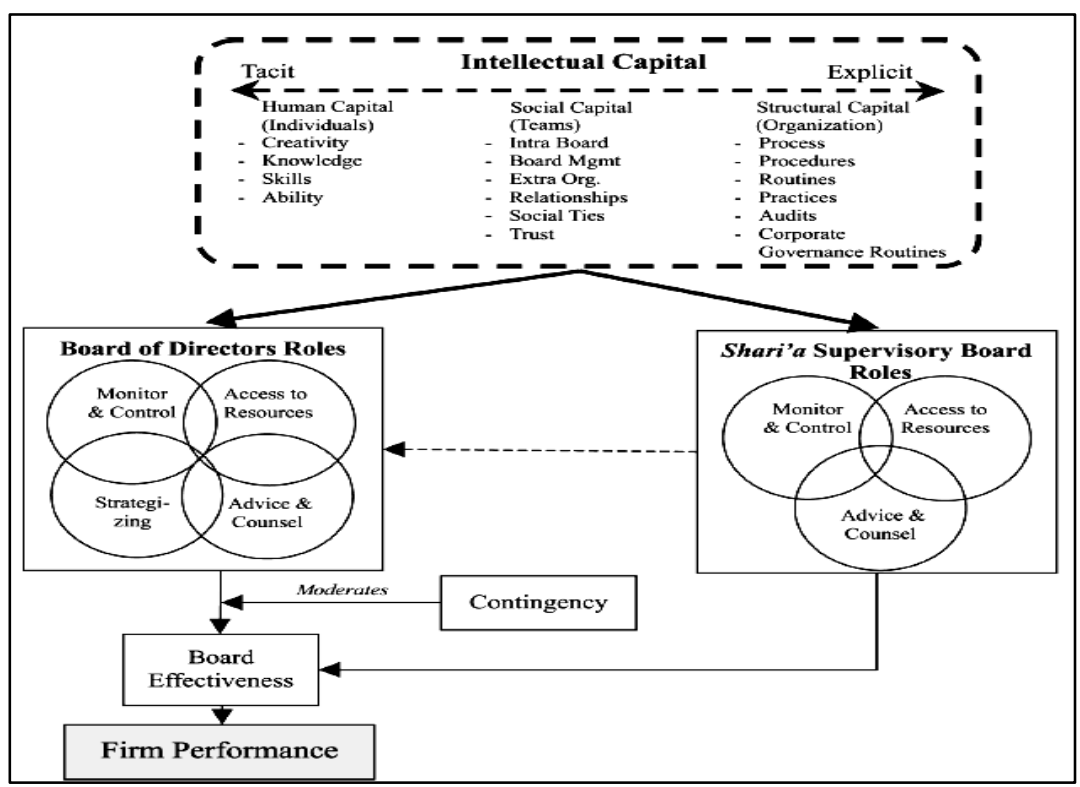

Figure 2: Intellectual Capital Model of Islamic Financial Institutions

Figure 2 shows that another segment of intellectual capital is social capital, which covers the diverse stages of social structures inside and outside of the organization. In this model, social capital comprises three stages, namely, interrelationship between the board and its external structures, interrelationship within the board, and interrelationship between the board and its management (Nicholson and Kiel, 2004). Board members are informed of a firm's activities that execute their role as members through relationships and interactions with the firm. However, the human capital development of the board members and the analysis of the information they receive before moving to the implementation stage are two of the main functions of company management (Kazemian, Rahman, Sanusi, \& Aedyemi, 2015).

Consequently, the relationships within the board, which constitute social capital, create awareness among the board members (Adil et al., 2013; Kamaluddin, Rahman, Mara, \& Alam, (2007). Hence, human and social capital are part and parcel of the board, and structural capital is a function of the board (Castanias and Helfat, 2001). Therefore, structural capital becomes the building block of an organization through the practices, strategies, and procedures of the board(Nick, 1999). Accordingly, structural capital is an integral component of an organization's board, where members share their implicit and explicit information by making their knowledge-based information beneficial to the other group members(Edvinsson \& Sullivan, 1996).

Dae-Bong (2009) asserted that the advanced measurement of human capital should consider the concept of "human development" with emphasis on social capital. An individual's social capital is substantially linked to his human capital, which is focused on the stock of knowledge, such as networking among constituents rather than isolated situations. The conventional measurement of human capital utilizes proxies (e.g., an individual's productivity) and education-related factors (e.g., high-level qualifications, graduation and enrollment rates, and time and financial investment in education). 
Furthermore, Alwi (2001)emphasized the significance of the human spirit among employees in the extended model of human capital from an Islamic organization's perspective by indicating that human capital should possess four values of the human spirit, namely, "Siddiq," the commitment to clean business processes, thereby leading to good corporate governance; "Amanah," the commitment to company vision, mission, and goals; "Tabligh," the formation of personal characteristics; and "Fathonah," the creative mindset. These four values create company culture and personality through good corporate governance, commitment to the needs and satisfaction of stakeholders, and continuous improvement.

Moreover, Rahman and Rahim (2010)described "Siddiq," "Amanah," "Fathonah," and "Tabligh" from the perspective of accountants and auditors as follows:

"Siddiq" means trustworthy, which relates to integrity and requires people to be competent and adequately qualified. The Qur'an (28:26) states that "truly the best of men to employ is the man who is strong and trustworthy." Muslims believe that man's ownership of anything in this world is not an end in itself but a means to provide a decent life for himself, his family, and society. Mankind is only a vicegerent of Allah in this world and will be held accountable for the way he has acquired and used wealth. In Islamic accounting and auditing, trustworthiness relates to a high degree of integrity, truthfulness, honesty, probity, and respect for the confidentiality of information.

"Amanah" means sincerity, which is based on the principle of man's obedience toward Allah (SWT) in performing his work. An accountant should not subject himself to external influences or pressures in performing his professional duties. This practice will lead to performing righteous deeds that enjoin all that are good and forbid all evil deeds.

"Tabligh" means piety, that is, the fear of Allah (SWT) in secret and in public by observing His commandments and avoiding His prohibitions. Man's work can become a form of worship of Allah (SWT) by observing "tabligh." An accountant should comply with Shariah laws in all professional duties. His accountability to Allah (SWT) should be over his accountability to other stakeholders.

"Fathonah" means righteousness. An accountant should not confine himself in performing his professional duties. Instead, he should strive to attain a high degree of righteousness and perfection in his work to the best of his ability. In the process, he should be objective by being fair, impartial, unbiased, free from conflicts of interest, and independent in fact and appearance.

In the noble teachings of Islam, Allah (SWT) is the sovereign and He has the right to ordain a path for the guidance of mankind(Mohd Ma'sum Billah, 2003). This teaching is the reason that Muslims strive to implement the spirit of Shariah, as stated in the Qur'an (45:18) and translated as follows:

"We made for you a Shariah, so follow it, and not the fancies of those who have no knowledge." 
To maintain fairness and honesty in any dealing that man may be involved in, Imam Razi stated the following words (Mohd Ma'sum Billah, 2003, p. 20):

"Take recourse to just balance and weight. Tell the truth in selling commodities and do not conceal anything."

Allah (SWT) does not want human beings to suffer difficulties, as stated in the Qur'an (2:185) and translated as follows:

"Allah (SWT) intends every facility for you; he does not want to put you in difficulties."

A Muslim community member is obliged to consider the socioeconomic and other concerns of family members, relatives, neighbors, community, and society. Moreover, a Muslim is required to consistently strive to purify himself from selfish tendencies toward others; a Muslim is likewise considered to have no faith if he does not express a caring attitude toward others (The Colombo Plan, 2007). These teachings reflect the importance of spirituality from the Islamic perspective.

Thus, we use the preceding discussions and arguments as bases to propose an extended model of human capital (from an Islamic organization's perspective) that embraces the elements of spiritual value in the human capital construct.

\section{Methodology}

Research Scope

To understand the human capital accountability of Islamic institutions, this study focuses on Islamic microfinance lenders in Malaysia and addresses human capital accountability as the correct or ideal evaluation method for human resources. This model incorporates the conventional perspectives discussed by Roos et al. (1997) and the human spirit elements discussed by Alwi (2001). The current study also considers the advance measurement method proposed by Dae-Bong (2009).

The present study collected data from managers of microfinance institutions (MFIs) in Malaysia. MFIs are financial institutions that have the social capital (i.e., commitment) to assist typically poor households and small enterprises in gaining access to financial services (Molla and Alam, 2011; Alam and Molla, 2012a, b). MFIs are distinguished from purely commercial, small-scale, and possibly informal financial institutions that deal with the poor (e.g., village moneylenders, pawnshops, and informal transfer systems) and from large, possible government-sponsored schemes that may hold small accounts as by-products of their main business (e.g., national savings schemes and postoffice savings banks) (Hardy, Holden, \& Prokopenko, 2002).

Islamic microfinance refers to a system of localized finance arrangements organized as an alternative source of funds for small, low-income clients who seek credit with the fulfillment of compliance given by Islamic law and way of life (Alam, Said, \& Salwana, 2015; Kamaluddin et al., 2015; Hassan et al., 2015). 


\section{Sample and Data Collection}

As of January 2013, Malaysia had 21 microfinance institutions classified as development financial institutions, commercial banks, non-bank institutions, and credit unions.

A total of 600 questionnaires were distributed among the managers of 120 financial institutions (main offices and their branches) that offer Islamic microfinance products and 44 Islamic MFIs (main offices and their branches) in Malaysia. Two to five questionnaires were sent to each organization and were addressed to the persons who were knowledgeable on human resources, accounting or finance, business development (including the marketing and corporate divisions), and organizational processes that include research and innovation activities.

However, only 60 questionnaires were returned, thereby yielding a response rate of 10\%. Data were collected using questionnaires, which were distributed via postal service. The questionnaires used five-point Likert scales (1-strongly disagree; 5strongly agree).

\section{Instrumentation and Validation}

The questionnaires comprised 74 items, which were divided into four main parts. Part 1 focused on human resource management and comprised four sections, namely, recruitment (Section A), selection of employees (Section B), performance evaluation (Section C), and training and compensation (Section D). Section A had five items, Section B had nine, Section C had eight, and Section D had seven.

Part 2 was on organizational human capital and comprised three sections, namely, knowledge and competencies (Section A), employee attitude (Section B), and employee spiritual value (Section C). Section A had thirteen questions, Section B had seven, and Section $\mathrm{C}$ had nine. Part 3 was concerned with organizational performance and consisted of seven questions. Lastly, Part 4 was on the profile of the respondents and comprised nine questions.

Prior to data collection, the instrument was content-validated and tested. The questionnaire items were adopted from established human capital and formed based on the information gathered from the interviews conducted previously. The indicators for human capital were reviewed by four experts, who are scholars in Islamic accounting and the Shariah board councils of the Islamic financial institutions.

\section{Results and Discussion}

\section{Respondent Profiles}

Data for this study were collected from the employees of MFIs in Malaysia. Table 1 shows that $37.3 \%$ of respondents are male and $62.7 \%$ are female. 
Table 1: Table of Frequencies for Gender

\begin{tabular}{|l|l|l|}
\hline Gender & Frequency & Percent \\
\hline Male & 22 & 37.3 \\
\hline Female & 37 & 62.7 \\
\hline Total & $\mathbf{5 9}$ & $\mathbf{1 0 0 . 0}$ \\
\hline $\mathbf{N = 5 9}$ & & \\
\hline
\end{tabular}

Table 2 shows the frequencies of job levels among the respondents from MFIs. Most of the respondents ( 27 or $45.8 \%$ ) are from low management levels and followed by those from middle management levels (20 or $33.9 \%$ ). A total of 7 (11.9\%) of the respondents are from senior management levels. Finally, 5 (8.5\%) of the respondents are from top management levels.

Table 2: Table of Frequencies for Job Level

\begin{tabular}{|l|l|l|}
\hline Job level & Frequency & Percent \\
\hline Low management level & 27 & 45.8 \\
Middle management level & 20 & 33.9 \\
\hline Senior management level & 7 & 11.9 \\
\hline Top management level & 5 & 8.4 \\
\hline Total & $\mathbf{5 9}$ & $\mathbf{1 0 0 . 0}$ \\
\hline $\mathbf{N}=\mathbf{5 9}$ & & \\
\hline
\end{tabular}

Table 3: Table of Frequencies for Job Specification

\begin{tabular}{|l|l|l|}
\hline & & \\
Job specification & Frequency & Percent \\
\hline Finance and accounting & 19 & 32.2 \\
\hline Human resources & 5 & 8.5 \\
\hline Sales and promotion & 8 & 13.6 \\
\hline Research and development & 4 & 6.8 \\
\hline Administration & 12 & 20.3 \\
\hline Others & 11 & 18.6 \\
\hline Total & $\mathbf{5 9}$ & $\mathbf{1 0 0 . 0}$ \\
\hline $\mathbf{N = 5 9}$ & & \\
\hline
\end{tabular}

Table 3 shows that respondents hold jobs belonging to six job classifications, namely, finance and accounting, human resources, sales and promotion, research and development, administration, and others. Most of the respondents (32.2\%) are from the finance and accounting departments. This group is followed by the respondents in administration $(20.3 \%)$ and those from departments in the "Others" category, such as microcredit (18.6\%). Lastly, $13.6 \%, 8.5 \%$, and $6.8 \%$ of the respondents come from sales and promotion, human resources, and research and development, respectively.

Correlation Test 
Table 4 presents the results of the Pearson correlation coefficient analysis, which was conducted to analyze the degree to which the variables are related(Pallant, 2010)and to ensure that multicollinearity, which is analyzed via the correlation coefficient $r$, does not exist among variables(Mohd. Radzi, 2012).

The results indicate positive and significant correlations among the human capital constructs. The correlation coefficients are between $r=0.107$ and 0.646 and are significant at $\mathrm{p}<0.01$. These results indicate that no multicollinearity problem exists among the variables under study.

Table 4: Summary of the Correlation Analysis Results

\begin{tabular}{|l|l|l|l|l|l|}
\hline No. & Items & 1 & 2 & 3 & 4 \\
\hline 1 & $\begin{array}{l}\text { Employee } \\
\text { knowledge and } \\
\text { competency }\end{array}$ & 1 & & \\
\hline 2 & $\begin{array}{l}\text { Employee } \\
\text { governance }\end{array}$ & $0.646^{* *}$ & 1 & & \\
\hline 3 & $\begin{array}{l}\text { Employee } \\
\text { commitment }\end{array}$ & $0.385^{* *}$ & $0.377^{* *}$ & 1 & \\
\hline 4 & $\begin{array}{l}\text { Employee } \\
\text { satisfaction }\end{array}$ & 0.118 & $0.107 * *$ & -0.034 & 1 \\
\hline$* *$ Correlation is significant at the 0.01 level (2-tailed)
\end{tabular}

\section{Factor Analysis}

A principal component analysis was conducted on the 29 human capital items. Table 5 presents the results. A varimax with Kaiser normalization exploratory factor analysis produced four dimensions (i.e., knowledge and competency, governance, commitment, and satisfaction), which account for $55.68 \%$ of the total variance with all of the factor loadings above 0.45 . The Kaiser-Meyer-Olkin measure of sampling adequacy was 0.724, which was beyond the recommended value of 0.6. The result of the Bartlett's test of sphericity was significant, thereby supporting the factorability of the correlation matrix.

Table 5: Factor's Value of the Human Capital Constructs

Knowledge and Competency

\begin{tabular}{|l|l|l|}
\hline Item & Descriptive & Coefficient \\
\hline KC1 & Are provided with proper Shariah training & 0.867 \\
\hline KC2 & Have experience in Shariah banking or matters & 0.807 \\
\hline KC3 & Are experts in handling matters pertaining to Shariah transactions & 0.747 \\
\hline KC4 & Are able to develop new ideas consistent with the Shariah principles & 0.714 \\
\hline KC5 & Possess right vocational training & 0.710 \\
\hline KC6 & Possess spiritual or religious character & 0.702 \\
\hline
\end{tabular}




\begin{tabular}{|l|l|l|}
\hline KC7 & Are self-developed & 0.679 \\
\hline KC8 & Previous job experience are related to their current position & 0.639 \\
\hline KC9 & Possess right academic qualification & 0.613 \\
\hline KC10 & Undergo succession training program & 0.608 \\
\hline KC11 & Are highly skilled & 0.570 \\
\hline KC12 & Are creative/innovative & 0.567 \\
\hline KC13 & Focus on the quality of service provided & 0.508 \\
\hline KC14 & Works well in a team & 0.413 \\
\hline
\end{tabular}

Governance

\begin{tabular}{|l|l|l|}
\hline Item & Descriptive & Coefficient \\
\hline GV1 & Are committed to stakeholders' needs and satisfaction & 0.813 \\
\hline GV2 & Are aware of stakeholders needs' and satisfaction & 0.723 \\
\hline GV3 & Are trustworthiness & 0.665 \\
\hline GV4 & Are widely considered the best in our industry & 0.617 \\
\hline GV5 & Are knowledgeable in Shariah principles & 0.497 \\
\hline
\end{tabular}

Commitment

\begin{tabular}{|l|l|l|}
\hline Item & Descriptive & Coefficient \\
\hline C1 & Maintain good relationships with their peers & 0.804 \\
\hline C2 & Are motivated & 0.793 \\
\hline C3 & Are committed to the organization & 0.789 \\
\hline C4 & Committed to achieve organizational mission and vision & 0.527 \\
\hline C5 & Practice teamwork & 0.519 \\
\hline
\end{tabular}

Satisfaction

\begin{tabular}{|l|l|l|}
\hline Item & Descriptive & Coefficient \\
\hline S1 & Are satisfied with the job environment & 0.863 \\
\hline S2 & Are generally satisfied working with us & 0.837 \\
\hline S3 & Are satisfied with the performance evaluation system & 0.830 \\
\hline S4 & Are high in turnover & 0.758 \\
\hline S5 & Only work under strict supervision & 0.370 \\
\hline
\end{tabular}

Extraction Method: Principal Axis Factoring

Rotation Method: Varimax with Kaiser Normalization

Bartlett's Test of Sphericity: Chi-Square: $1252.630, \mathrm{df}=406, \mathrm{p}=0.00$

Kaiser-Meyer-Olkin Measure of Sampling Adequacy $=0.724$

\section{Reliability Tests}

The normality and reliability test results indicate that the data used for this study meet the levels of reliability required for significant analyses. The Cronbach's $\alpha$ of human capital and performance are 0.919 and 0.846 , respectively.

\section{Conclusion}

This study proposes the definition and measurement of human capital from the Islamic perspective. The results of the current model suggest that the measurement of Islamic human capital model comprises four constructs, namely, knowledge and competency, governance, commitment, and satisfaction. This research discovers that spiritual values, namely, "Siddiq," "Amanah," "Tabligh," and "Fathonah," are embraced in all the constructs of human capital. The factor analysis results reflect that "knowledge" in this 
context includes knowledge in Shariah principles and jurisprudence; capabilities include the ability to innovate and create unique products or services that are consistent with the requirement of Islamic jurisprudence.

Another construct is defined as "governance," which signifies that people are committed to clean business processes ("Siddiq") that are represented by the indicators "committed and aware to stakeholders" needs and satisfaction," "trustworthiness," and "considered the best in the industry."

The "commitment" construct refers to the commitment of people toward achieving their organization's vision and mission, maintaining good relationships with peers, and applying strong teamwork. This construct is consistent with "Amanah," which means sincerity in performing duties. The final construct is "satisfaction," which reveals the character, behavior, and conduct of employees.

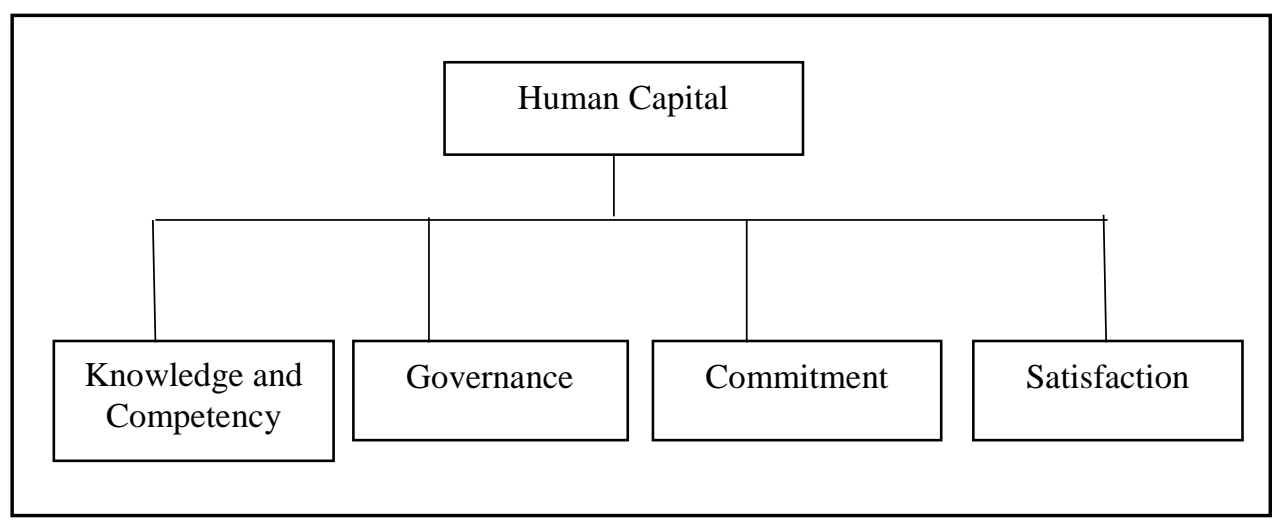

Figure 3: Human Capital from the Islamic Perspective

Consistent with Abdullah (2012)human capital in Islam is not restricted to the abilities, competencies, and experiences of human beings but also possesses "Siddiq" (trustworthy), "Amanah" (sincerity), "Tabligh" (piety), and "Fathonah" (righteousness) to provide improved services to the community and society. These human elements are essential for managers of MFIs when serving poor communities by extending microfinance assistance, thereby enabling recipients to carry out their economic activities and improve their standard of living.

Allah (SWT) also said the following words, "I will create a vicegerent on earth (2:30)," which implies that the aim of human capital is as follows:

....is to fulfill the objective of the successor (Khalifah) on the earth. This goal will not be accomplished unless man is competent enough to fulfill these duties adequately and potently, thereby qualifying him, raising his abilities, and releasing his powers and capabilities in different physical, intellectual, psychological, and spiritual aspects (International Islamic Jurisprudence Academy, 2007; Abdullah, 2012).

The current study offers several contributions to the human capital measurement literature by extending the conventional definitions of human capital proposed by previous scholars. Through the lens of Islam, the current study substantiates that the 
spiritual values "Siddiq" (trustworthy), "Amanah" (sincerity), "Tabligh" (piety), and "Fathonah" (righteousness) are components of human capital characteristics. These characteristics are indispensable for managers to ensure the efficiency and effectiveness of their roles as leaders in their organizations. The current study proposes that the human capital construct encompasses human competency and knowledge, as well as include governance, commitment, and satisfaction. In addition, this study introduces the measurement of human capital based on indicators. The conventional approach in measuring human capital is focused on output, cost, and income. To further test the proposed human capital model, this study should be extended to other Islamic organizations, such as banks and religious institutions.

\section{Acknowledgment}

We would like to thank the Accounting Research Institute of the Universiti Teknologi MARA and the Ministry of Higher Education Malaysia for providing financial support to this research project. We are grateful for the grant, without which we would not have been able to conduct this research.

\section{References}

Abdullah, M. F. (2012). The role of Islam in human capital development: a juristic analysis. Humanomics, 28(1), 64-75.

Al-Ali, N. (2003). Comprehensive Intellectual Capital Management: Step-by-Step. New Jersey: John Wiley \& Sons, Inc.

Alwi, S. (2001). Manajemean Sumber Daya Manusia: Strategi Keunggulan Kompetitif. BPFE, Yogyakarta.

Aradhana, K., \& Anuradha, S. (2005). Managing human resource capabilities for sustainable competitive advantage: An empirical analysis from Indian global organisations. Education + Training, 47(8/9), 628-639.

Aziz, Z. A. (2007, 14 May). The global Islamic financial services industry. Speech by Dr Zeti Akhtar Aziz, Governor of the Central Bank of Malaysia, at the Launch of Kuwait Finance House Research, Dubai. Retrieved from http://www.bis.org/review/r07015b.pdf

Baron, A. (2011). Measuring human capital. Strategic HR Review, 10(2), 30-35.

Bassi, L. J., \& Buren, M. E. V. (1999). Valuing investments in intellectual capital. International Journal of Technology Management, 18(5-8), 414-432.

Brinker, B. (2005, May ). Intellectual capital: tomorrow's asset, today's challenge. Retrieved from http://www.cpavision.org/vision/wpaper05b.cfm

Castanias, R. P., \& Helfat, C. E. (2001). The managerial rents model: Theory and empirical analysis. Journal of Management, 27(6), 661-678.

Coakes, S. J. (2005). SPSS version 12.0 for Windows : analysis without anguish. Milton, Qld.: John Wiley \& Sons.

Darus, F., Mad, S., \& Yusoff, H. (2014). The importance of ownership monitoring and firm resources on corporate social responsibility (CSR) of financial institutions. Procedia-Social and Behavioral Sciences, 145, 173-180.

Davenport, T. O. (1999). Human Capital. Management Review, 88(11), 37.

Edvinsson, L., \& Sullivan, P. (1996). Developing a model for managing intellectual capital. European Management Journal, 14(4), 356-364. 
Hardy, D. C., Holden, P., \& Prokopenko, V. (2002). Monetary and Exchange Affairs Department. Microfinance Institutions and Public Policy, IMF Working Paper.

Hermans, R., \& Kauranen, I. (2005). Value creation potential of intellectual capital in biotechnology - empirical evidence from Finland. $R \& D$ Management, 35(2), 171-185.

Hubert, S. O. (1996). Tacit knowledge the key to the strategic alignment of intellectual capitalnull. Planning Review, 24(2), 10-16. doi:10.1108/eb054547

Kamaluddin, A., Rahman, R., Mara, U., \& Alam, S. (2007). The moderating effect of organisation culture on intellectual capital and organisational effectiveness relationships. Paper presented at the International Conference on Intellectual Capital, Knowledge Management \& Organizational Learning.

Kamaluddin, A., \& Rahman, R. A. (2013). The intellectual capital model: the resourcebased theory application. . International Learning and Intellectual Capital, 10(3-4), 294-313.

Kazemian, S., Abdul Rahman, R., \& Ibrahim, Z. (2014). Measuring level of market orientation for an Islamic microfinance institution case study of Amanah Ikhtiar Malaysia (AIM). Qualitative Research in Financial Markets, 6(3), 258-277.

Kazemian, S., Abdul Rahman, R., Mohd Sanusi, Z., \& Adeyemi, A. A. (2016). Role of market orientation in sustainable performance: the case of a leading microfinance provider. Humanomics, 32(3).

Kazemian, S., Rahman, R. A., Sanusi, Z. M., \& Aedyemi, A. A. (2015). Can Market Orientation Sustain Management of Microfinance Institutions? The Case Study of Amanah Ikhtiar Malaysia (AIM) A New Paradigm for International Business (pp. 271-283): Springer.

Mohd Ma'sum Billah. (2003). Modern Financial Transactions under Shariah. Ilmiah Publishers, Petaling Jaya, Malaysia, 5.

Mohd. Radzi, S. H. (2012). Tax Reporting for Non-Profit Organization in Malaysia. Retrieved from

Nicholson, G. J., \& Kiel, G. C. (2004). Breakthrough board performance: how to harness your board's intellectual capital[1]null. Corporate Governance: The international journal of business in society, 4(1), 5-23.

Nick, B. (1998). Intellectual capital: an exploratory study that develops measures and modelsnull. Management Decision, 36(2), 63-76.

Nick, B. (1999). Managing Organizational Knowledge by Diagnosing Intellectual Capital: Framing and Advancing the State of the Field. International Journal of Technology Management, 18(5-8), 433-462.

Pallant, J. (2010). SPSS Survival Manual: A Step By Step Guide to Data Analysis Using SPSS Program (4th ed.): The McGraw Hill.

Paula, B., \& Michela, C. (2010). Interaction between structural capital and human capital in Italian NPOs: Leadership, organizational culture and human resource management. Journal of Intellectual Capital, 11(2), 123-139.

Qfinance. (2009, April). Islamic microfinance. Retrieved from http://www.qfinance.com/financing-checklists/islamic-microfinance

Rahman, A., \& Rahim, A. (2010). An introduction to Islamic accounting theory and practice. Kuala Lumpur: CERT Publication.

Roos, J., Roos, G., Dragonetti, N. C., \& Edvinsson, L. (1997). Intellectual Capital. Navigating In the New Business Landscape. London: Macmillan Press Ltd. 
Seetharaman, A., Kevin Lock Teng, L., \& Saravanan, A. S. (2004). Comparative justification on intellectual capital. Journal of Intellectual Capital, 5(4), 522539.

Shuhidan, S. M., Said, J., Mokri, S. H., \& Kazemian, S. (2016). Market orientation within technological companies: Risk based approach. Paper presented at the Computer and Information Sciences (ICCOINS), 2016 3rd International Conference on.

Stewart, T. A. (2002). The Wealth of Knowledge. London: Nicholas Brealey.

Tseng, C.-Y., \& James Goo, Y.-J. (2005). Intellectual capital and corporate value in an emerging economy: empirical study of Taiwanese manufacturers. $R \& D$ Management, 35(2), 187-201.

Uliana, E., Macey, J., \& Grant, P. (2005). Towards reporting human capital. Meditari Accountancy Research, 13(2), 167-188.

Wright, P. M., McMahan, G. C., \& McWilliams, A. (1994). Human resources and sustained competitive advantage: a resource-based perspective. The International Journal of Human Resource Management, 5(2), 301-326. 